\title{
Preparation of Fe73Cr18Ni9 Alloy Powder from Nano-Fe73Cr18Ni9 Composite Oxide by Hydrogen Co-reduction Process
}

\author{
Hui-Min YU ${ }^{a}$, Zai-Yuan LI ${ }^{b}$ \\ College of Materials and Metallurgy, Northeastern University, Shenyang, 110004, P.R. China \\ a1329693214@qq.com, blizy@smm.neu.edu.cn
}

Keywords: Nano-oxide Powder, Fe73Cr18Ni9, Co-precipitation, Hydrogen Co-reduction, Alloy Powder.

\begin{abstract}
In this paper, $\mathrm{Fe} 73 \mathrm{Cr} 18 \mathrm{Ni} 9$ composite oxide nano-powder was prepared by chemical co-precipitation method taking $\mathrm{FeSO}_{4} \cdot 7 \mathrm{H}_{2} \mathrm{O}, \mathrm{CrCl}_{3} \cdot 6 \mathrm{H}_{2} \mathrm{O}, \mathrm{NiSO}_{4} \cdot 6 \mathrm{H}_{2} \mathrm{O}$ and $\mathrm{NaOH}$ as raw materials. Its particle size was about $50 \mathrm{~nm}$. Then $\mathrm{Fe} 73 \mathrm{Cr} 18 \mathrm{Ni} 9$ alloy powder was obtained by hydrogen co-reduction process taking advantage of active nano-characteristics of $\mathrm{Fe} 73 \mathrm{Cr} 18 \mathrm{Ni} 9$ composite oxide nano-powder at $1000^{\circ} \mathrm{C}$ after $1.5 \mathrm{~h}$ of co-reduction. Its particle size was about $300 \mathrm{~nm}$.
\end{abstract}

\section{Introduction}

Nano-oxide powder(1 100nm) has some unique properties, such as small particle size, large specific surface area, quantum size effect, macroscopic quantum tunneling effect, which has some new characteristics compared with common oxide powder. Therefore, the preparation, properties and further application of nano-oxide powder have attracted extensive attention recently [1-15].

Metal oxide nano-powder has many advantages ,such as small size, incomplete crystal structure on the surface, many active sites, which greatly improved its reaction activity. Because of the large specific surface area, the hydrogen reduction reaction speed of nano-metal oxide powder has increased. There have been some reports on the microtherm preparation of metal, alloy and composite metal powder taking advantage of the high activity of nano-metal oxide and nano-metal composite oxide powder[16-19].

However, it is difficult to obtain metallic chromium by direct reduction of high valent chromium oxide. So the preparation of $\mathrm{Cr}$ powder by direct hydrogen reduction of nano- $\mathrm{Cr}_{2} \mathrm{O}_{3}$ powder has scarcely been reported so far, and the same thing happens to the preparation of $\mathrm{Fe} 73 \mathrm{Cr} 18 \mathrm{Ni} 9$ alloy powder from Fe73Cr18Ni9 nano composite oxide powder.

Fe73Cr18Ni9 alloy powder is the raw material of Cr18Ni9 stainless steel powder, which is widely used in powder metallurgy, corrosion coating, filter material and other industries[20-22]. The most frequently used methods to obtaine stainless steel powder include mechanical alloying[23], gas-solid flow atomization method[24], supersonic gas atomization[25] and high energy milling method[26], etc.

Hydrogen is a kind of renewable, clean energy which can be used as a reducing agent and could gradually replace carbon. As the problems of resources depletion, environment and global warming become serious, it is of great significance to study the process of hydrogen reduction.

In this paper, $\mathrm{Fe} 73 \mathrm{Cr} 18 \mathrm{Ni} 9$ alloy powder was obtained by directly reducing $\mathrm{Fe} 73 \mathrm{Cr} 18 \mathrm{Ni} 9$ composite oxide nano-powder with hydrogen at $1000^{\circ} \mathrm{C}$ by taking advantages of high activity of nano-powder.

\section{Experiment}

Experimental apparatus: drying oven, acidmeter, electric blenders, vacuum pump, and closed cycle hydrogen reduction furnace, etc.

Chemical reagents: $\mathrm{NiSO}_{4} \cdot 6 \mathrm{H}_{2} \mathrm{O}, \mathrm{CrCl}_{3} \cdot 6 \mathrm{H}_{2} \mathrm{O}, \mathrm{FeSO}_{4} \cdot 7 \mathrm{H}_{2} \mathrm{O}, \mathrm{NaOH}$, anhydrous ethanol, all of which are chemical pure; hydrogen, nitrogen.

Preparation of the aqueous solution of $\mathrm{FeSO}_{4}-\mathrm{CrCl}_{3}-\mathrm{NiSO}_{4}$ : Some $\mathrm{FeSO}_{4} \cdot 7 \mathrm{H}_{2} \mathrm{O}, \mathrm{CrCl}_{3} \cdot 6 \mathrm{H}_{2} \mathrm{O}$, 
$\mathrm{NiSO}_{4} \cdot 6 \mathrm{H}_{2} \mathrm{O}(\mathrm{Fe}: \mathrm{Cr}: \mathrm{Ni}=73: 18: 9, \mathrm{wt} \%)$ were dissolved in a certain amount of deionized water. After removing the insoluble impurities by filtration, $\mathrm{FeSO}_{4}-\mathrm{CrCl}_{3}-\mathrm{NiSO}_{4}$ mixtures solution of 0.1 mol-L-1 was obtained.

Preparation of aqueous solution of $\mathrm{NaOH}$ : $\mathrm{NaOH}$ solution of $4 \mathrm{~mol} \cdot \mathrm{L}-1$ was achieved by solving some $\mathrm{NaOH}$ into a certain amount of de-ionized water and the successively filtrating of insoluble impurities.

Preparation of Fe73Cr18Ni9 composite oxide nano-powder: $500 \mathrm{~mL}$ of $0.1 \mathrm{~mol} \cdot \mathrm{L}-1$ $\mathrm{FeSO}_{4}-\mathrm{CrCl}_{3}-\mathrm{NiSO}_{4}$ mixed solution was put in a beaker, and then $4 \mathrm{~mol} \cdot \mathrm{L}-1 \mathrm{NaOH}$ solution was dripped with a strong stir. The $\mathrm{pH}$ value of the end of the reaction was 11. By dropping the deposit into alcohol for several hours, the Fe73Cr18Ni9 composite oxide nano-powder was obtained.

Preparation of Fe73Cr18Ni9 nano-powder: The Fe73Cr18Ni9 composite oxide nano-powder placed in a porcelain crucible was put into cooling zone (the 3 condensator in Fig.1) of the closed cycle hydrogen-reduction furnace. The three-way valve was placed in the status of gas replacement, and $\mathrm{N}_{2}$ gas was using for the elimination of air. Hydrogen was pumped in, and the whole system was set on the closed circulation status, then hydrogen would pass through the system, during which hydrogen and nitrogen was circulated in the system by gas pump. After the reduction furnace was heated to desired constant temperature, the Fe73Cr18Ni9 composite oxide nano-powder was reduced in constant temperature zone. The pressure change was also recorded in the system. The reaction is over when the pressure of the system would not decrease. The reduced powder was quickly pushed to cooling zone (the 6 condensator in Fig.1), and then take out when it was cooled down to room temperature.

Samples examination: The samples were examined by X-ray diffractometer (XRD), scanning electron microscope (SEM) and Transmission electron microscope (TEM).

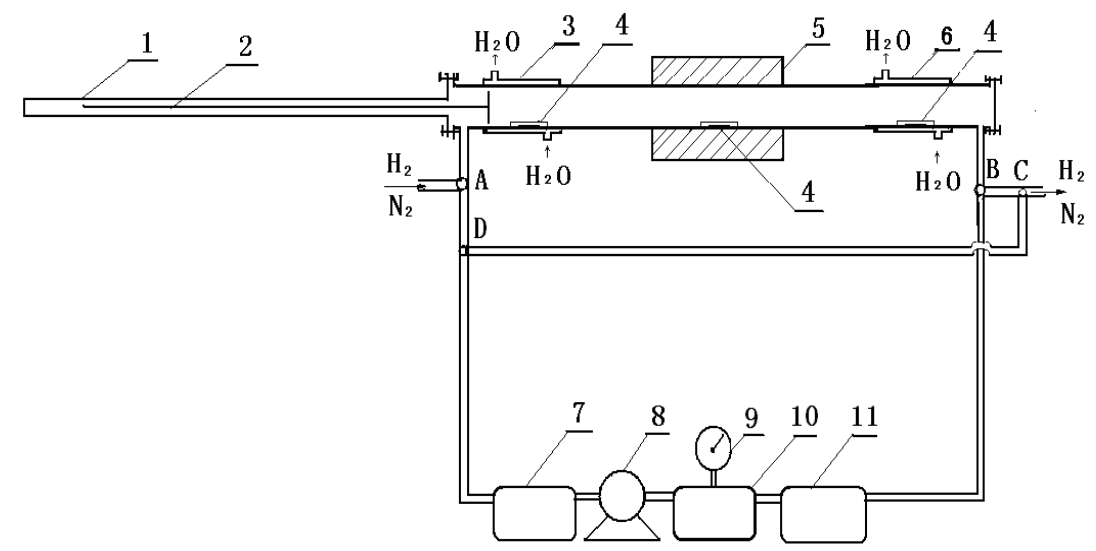

1-Latex sheath, 2-push sample implement, 3and 6-condensator, 4-porcelain crucible and sample, 5-reduction furnace of temperature controller, 7 and 10-buffer bottles, 8-gas pump, 9-manometer, 11-moisture removing apparatus, $A, B, C, D$ - the three-way valve. $A \rightarrow 4 \rightarrow B \rightarrow 8 \rightarrow D \rightarrow C$ was path of the system gas replacement; $\mathrm{A} \rightarrow 4 \rightarrow \mathrm{B} \rightarrow 8 \rightarrow \mathrm{D} \rightarrow \mathrm{A}$ was path of the system closed circulation.

Fig. 1 Schematic diagram of the closed circulation-hydrogen reduction system

\section{Results and Discussions}

\section{Influence of Particle Size of Fe73Cr18Ni9 Composite Oxide Powder on the Hydrogen Co-reduction Process}

The Fe73Cr18Ni9 composite oxide nano-powder was prepared by co-precipitation. The reaction conditions were as follows: reaction temperature of $25^{\circ} \mathrm{C}$; reaction time of $35 \mathrm{~min}$; stirring speed of 1000rpm; $\mathrm{PH}$ value of 11 for terminal reaction; drying time of $48 \mathrm{~h}$; drying temperature of $25^{\circ} \mathrm{C}, 100^{\circ} \mathrm{C}, 150^{\circ} \mathrm{C}$, respectively. The SEM analytic results were shown in Fig.2. The Fe73Cr18Ni9 alloy powder was prepared at $1000^{\circ} \mathrm{C}$ after $1.5 \mathrm{~h}$ of co-reduction. The SEM and XRD pattern of the final reduction products was shown in Fig.3 and Fig.4. 
The Fig.2(a) 2(c) shows that with the increase of drying temperature, the particle size of Fe73Cr18Ni9 composite oxide powder was increased.

The Fig.3(a) 3(c) shows that the higher the Fe73Cr18Ni9 composite oxide powder particle size, the higher the $\mathrm{Fe} 73 \mathrm{Cr} 18 \mathrm{Ni} 9$ alloy powder particle size.

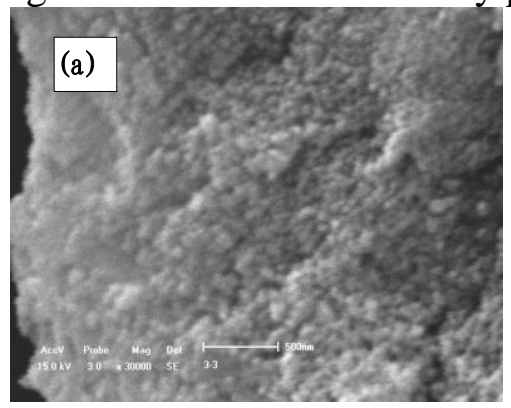

(a) $25^{\circ} \mathrm{C}$ dryness 48 hour,

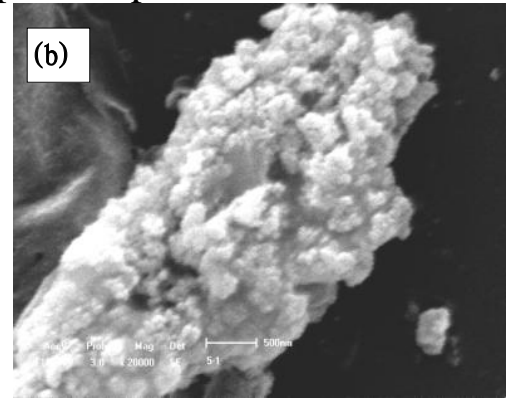

(b) $100^{\circ} \mathrm{C}$ dryness 48 hour,

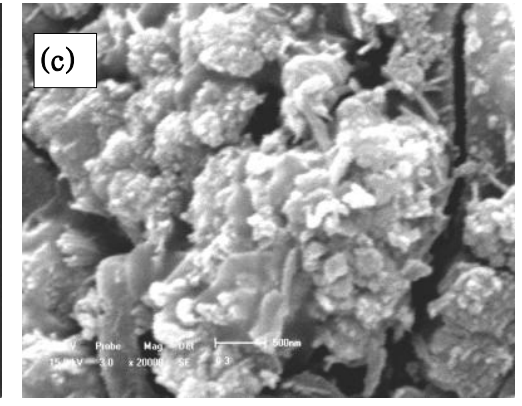

(c) $150^{\circ} \mathrm{C}$ dryness 48 hour

Fig.2 SEM image of Fe73Cr18Ni9 composite oxide powder

It indicated that the lower the temperature, the fewer the diffraction peaks of XRD. The Fe73Cr18Ni9 composite oxide nano-powder was obtained at drying temperature of $25^{\circ} \mathrm{C}$. The Fe73Cr18Ni9 alloy powder was prepared at $1000^{\circ} \mathrm{C}$ after $1.5 \mathrm{~h}$ of co-reduction. As the drying temperature increased, the particle size of the $\mathrm{Fe} 73 \mathrm{Cr} 18 \mathrm{Ni} 9$ composite oxide nano-powder increased, which resulted in lower reduction rate. Sample (b) and sample (c) were needed higher reduction temperature or longer reduction time.
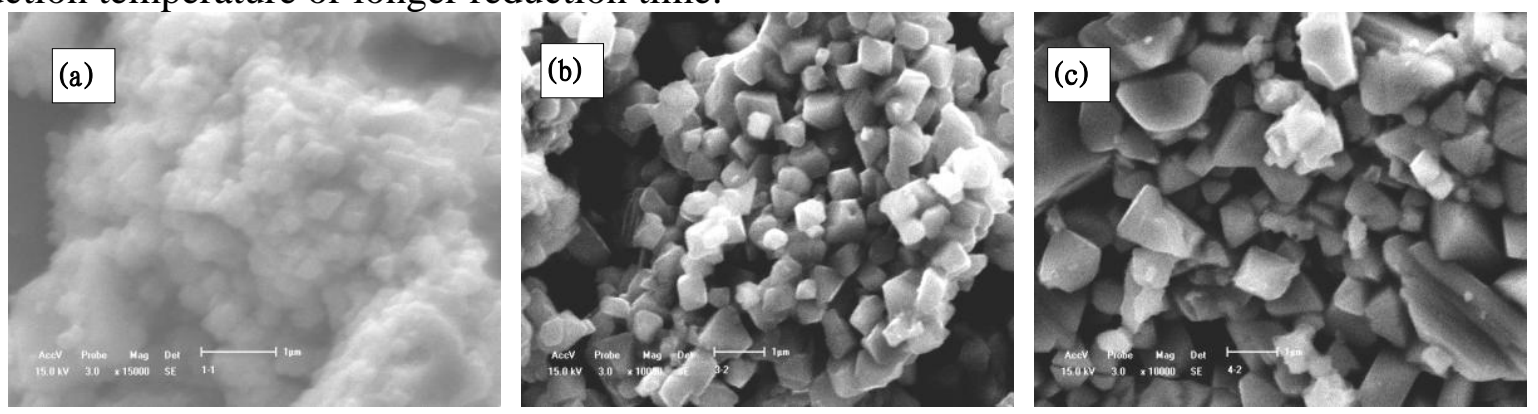

The Fe73Cr18Ni9 composite oxide powder dryness temperature was (a) $25^{\circ} \mathrm{C}$, (b) $100^{\circ} \mathrm{C}$, (c) $150^{\circ} \mathrm{C}$

Fig.3 SEM image of Fe73Cr18Ni9 alloy powder

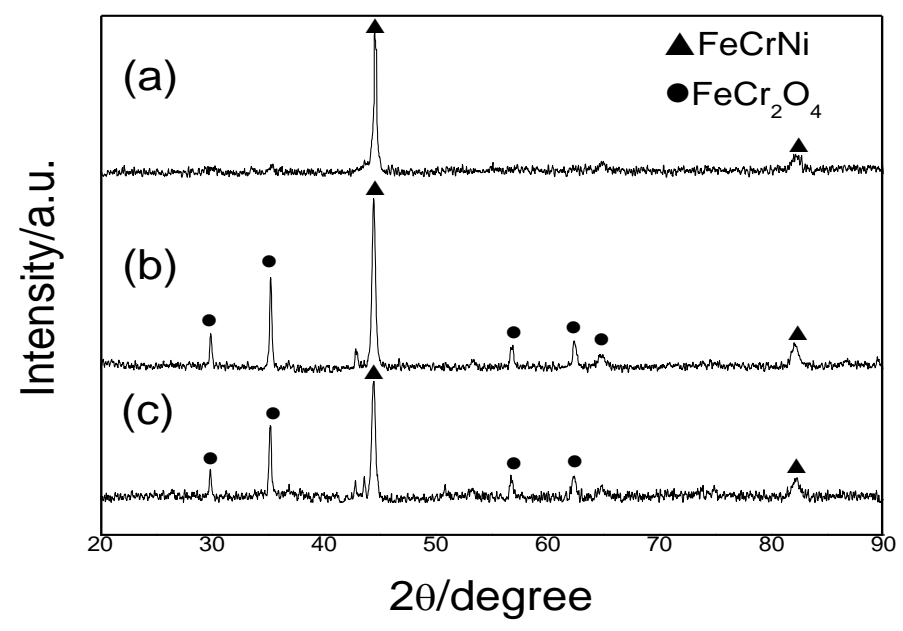

Fig. 4 XRD pattern of the final reduction product obtained by $2 \mathrm{~h}$ of reduction at $1000^{\circ} \mathrm{C}$ from the

Fe $73 \mathrm{Cr} 18 \mathrm{Ni9}$ composite oxide nano-powder dried at (a) $25^{\circ} \mathrm{C}$, (b) $100^{\circ} \mathrm{C}$ and (c) $150^{\circ} \mathrm{C}$, respectively 


\section{Influence of Reaction Temperature on the Hydrogen Co-reduction Process}

The Fe73Cr18Ni9 composite oxide nano-powder was placed in a porcelain boat, and pushed into the closed reduction furnace cooling zone. When the temperature reached $800{ }^{\circ} \mathrm{C}, 900{ }^{\circ} \mathrm{C}$ and $1000{ }^{\circ} \mathrm{C}$ respectively, and another 5 minutes was kept to make temperature of the system homogenous, the Fe73Cr18Ni9 composite oxide nano-powder was pushed into the constant temperature zone quickly to reduce the oxide powder by hydrogen. After $1.5 \mathrm{~h}$ reaction, the Fe73Cr18Ni9 composite oxide nano-powder was moved to the cooling zone of the reduction furnace.

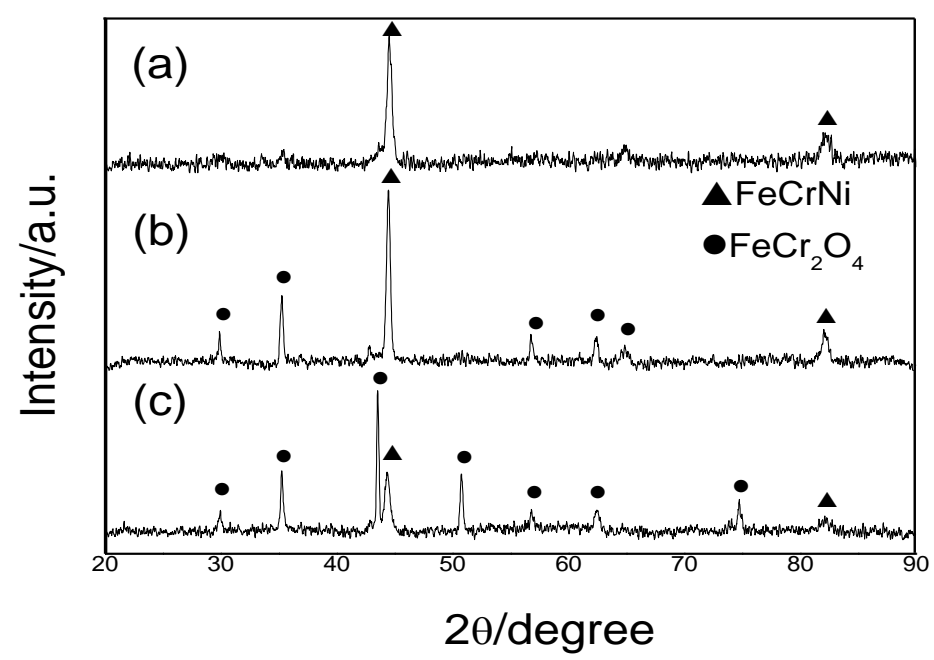

Fig.5 XRD patterns of the products obtained by hydrogen reduction of the Fe73Cr18Ni9 composite oxide nano-powder for $2 \mathrm{~h}$ at (a) $1000^{\circ} \mathrm{C}$, (b) $900^{\circ} \mathrm{C}$ and (c) $800^{\circ} \mathrm{C}$, respectively.

Fig. 5 was the XRD patterns of the reduction products at $800^{\circ} \mathrm{C}, 900^{\circ} \mathrm{C}, 1000^{\circ} \mathrm{C}$, respectively. The results showed that the $\mathrm{Fe} 73 \mathrm{Cr} 18 \mathrm{Ni} 9$ alloy powder was obtained at $1000{ }^{\circ} \mathrm{C}$ after $1.5 \mathrm{~h}$ of co-reduction. When the reaction temperature increased, the impurities in the product decreased, and hydrogen reduction of the oxide powder was more complete.

\section{Influence of Reaction Time on the Hydrogen Co-reduction Process}

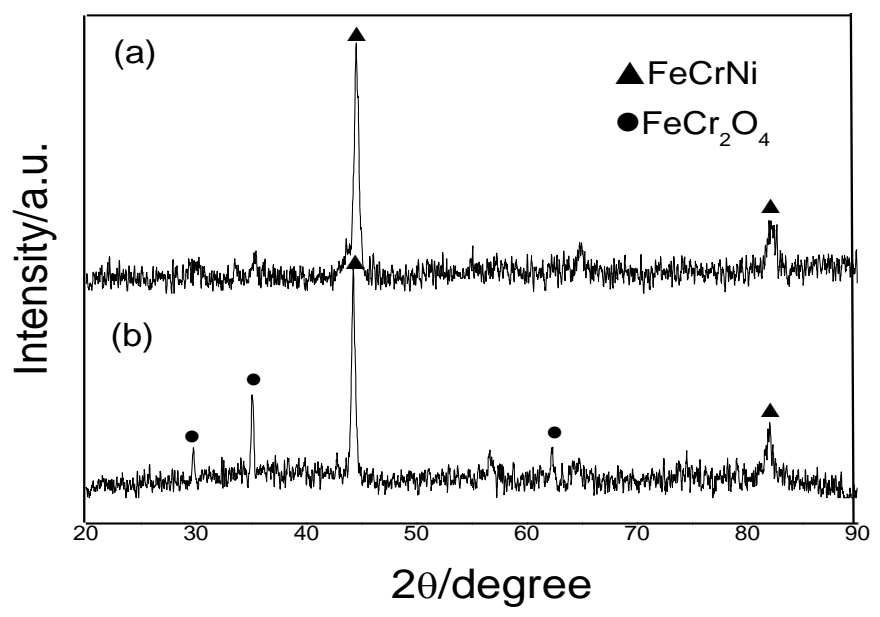

Fig.6 XRD patterns of the products obtained by hydrogen reduction of the Fe73Cr18Ni9 composite oxide powder at $1000^{\circ} \mathrm{C}$ for (a) $1.5 \mathrm{~h}$ and (b) $1 \mathrm{~h}$, respectively. 
The Fe73Cr18Ni9 composite oxide nano-powder was placed in a porcelain boat, and pushed into the closed reduction furnace cooling zone. When the temperature reached $1000^{\circ} \mathrm{C}$ and another 5 minutes was kept to make temperature of the system homogenous, the Fe73Cr18Ni9 composite oxide nano-powder was pushed into the constant temperature zone quickly to reduce the oxide powder by hydrogen. After $1 \mathrm{~h}, 1.5 \mathrm{~h}$ of reaction respectively, the porcelain boat was moved to the cooling zone of the reduction furnace. Fig. 6 was XRD patterns of the reduction product.

Fig.6 shows that the $\mathrm{Fe} 73 \mathrm{Cr} 18 \mathrm{Ni} 9$ alloy powder was obtained at $1000{ }^{\circ} \mathrm{C}$ after $1.5 \mathrm{~h}$ of co-reduction. When the reaction time increased, the impurities in the product decreased, and hydrogen reduction of the oxide powder was more complete.

\section{Influence of Temperature System on the Hydrogen Co-reduction Process}

Sample (a): The Fe73Cr18Ni9 composite oxide nano-powder in a small porcelain boat was placed in the cooling zone of the furnace. When the temperature reached $1000{ }^{\circ} \mathrm{C}$, another 5 minutes was successively kept, then the porcelain boat was pushed into the constant temperature zone for 1.5h of hydrogen reduction. XRD pattern was shown in Fig.7(a).

Sample (b): The Fe73Cr18Ni9 composite oxide nano-powder in a small porcelain boat was placed in the constant temperature zone, and the furnace was heated to $1000^{\circ} \mathrm{C}$ at a rate of $15^{\circ} \mathrm{C}$ $\cdot \mathrm{min}^{-1}$ for $2 \mathrm{~h}$ of hydrogen reduction, whose XRD pattern was presented in Fig.7(b).

Sample (c): The $\mathrm{Cr}(\mathrm{OH})_{3}$ nano-powder was prepared by the method of precipitation at following conditions: reaction temperature of $25^{\circ} \mathrm{C}$, reaction time of $35 \mathrm{~min}$, stirring speed of 1200rpm, $\mathrm{PH}$ value of 11 for terminal reaction, drying temperature of $25^{\circ} \mathrm{C}$, drying time of $48 \mathrm{~h}$ and using $\mathrm{CrCl}_{3} \cdot 6 \mathrm{H}_{2} \mathrm{O}, \mathrm{NaOH}$ as raw materials. The powder was reduced by hydrogen under in the same conditions to those in the preparation of sample (c). The XRD analysis of the reduction product was shown in Fig. 7(c).

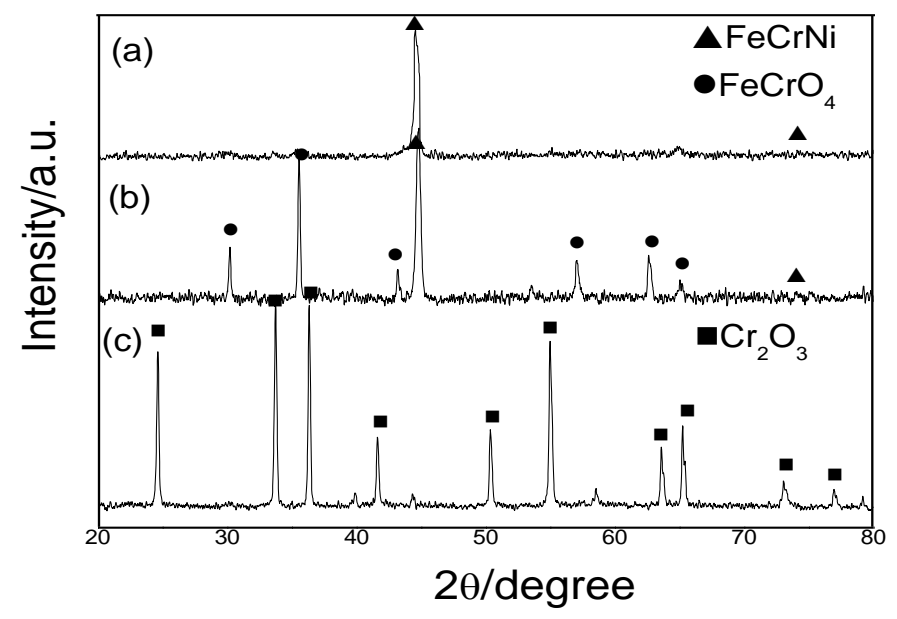

Fig.7 XRD pattern of the final reduction product in (a) sample A, (b) sample B and sample C, respectively

The Fig.7(c) shows that $\mathrm{Cr}(\mathrm{OH})_{3}$ can not be reduced by hydrogen. According to Eq.1, the theatrical temperature for the reduction of $\mathrm{Cr}_{2} \mathrm{O}_{3}$ is about $4610.48^{\circ} \mathrm{C}$ under the standard state.

$$
\begin{aligned}
& \frac{1}{3} \mathrm{Cr}_{2} \mathrm{O}_{3}+\mathrm{H}_{2}=\frac{2}{3} \mathrm{Cr}+\mathrm{H}_{2} \mathrm{O} \\
& \Delta \mathrm{G}^{\mathrm{O}}=26147.7-30.8 \mathrm{~T} / \mathrm{K}
\end{aligned}
$$

The Fig. 7(a) shows that at the same experimental conditions, the composite oxide nano-powder, including $\mathrm{Fe}, \mathrm{Cr}$, Ni three elements, was quickly pushed into $1000^{\circ} \mathrm{C}$ constant temperature zone to 
take $1.5 \mathrm{~h}$ reduction reaction, and was reduced to $\mathrm{Fe} 73 \mathrm{Cr} 18 \mathrm{Ni} 9$ alloy powder.

The composite oxide nano-powder along with the reduction furnace was heated to $1000^{\circ} \mathrm{C}$ with the rate of $15^{\circ} \mathrm{C} \cdot \mathrm{min}^{-1}$, and was reduced for 1.5 hours. $\mathrm{FeC}_{\mathrm{r} 2} \mathrm{O}_{4}$ was still in reduction products. Reduction reaction was incomplete. This shows that Fe73Cr18Ni9 composite oxide powder's particle size was increased at rise temperature process.

\section{Conclusions}

The Fe73Cr18Ni9 composite oxide powder was prepared at the reaction end point of $\mathrm{pH}$ of 11 , the reaction time of $35 \mathrm{~min}$, the stirring rate of $1200 \mathrm{rpm}$, the reaction temperature of $30^{\circ} \mathrm{C}, \mathrm{NaOH}$ solution concentration of $4 \mathrm{~mol} \cdot \mathrm{L}^{-1}, \mathrm{FeSO}_{4}-\mathrm{CrCl}_{3}-\mathrm{NiSO}_{4}$ mixed solution concentration of 0.1 $\mathrm{mol} \cdot \mathrm{L}^{-1}$ and the dropping rate of $\mathrm{NaOH}$ solution of $50 \mathrm{ml} \cdot \mathrm{min}^{-1}$. Its particle size was about $50 \mathrm{~nm}$. With the increase of drying temperature, the particle size of $\mathrm{Fe} 73 \mathrm{Cr} 18 \mathrm{Ni} 9$ composite oxide powder was increased.

Then Fe73Cr18Ni9 alloy powder was obtained by hydrogen co-reduction process taking advantage of active characteristics of $\mathrm{Fe} 73 \mathrm{Cr} 18 \mathrm{Ni} 9$ composite oxide nano-powder at $1000^{\circ} \mathrm{C}$ after $1.5 \mathrm{~h}$ of co-reduction. Its particle size was about $300 \mathrm{~nm}$. The particle size of the $\mathrm{Fe} 73 \mathrm{Cr} 18 \mathrm{Ni} 9$ composite oxide nano-powder increased, the $\mathrm{Fe} 73 \mathrm{Cr} 18 \mathrm{Ni} 9$ alloy powder particle size was increased, reduction rate was slower.

\section{Acknowledgements}

The authors acknowledge the National Natural Science Foundation of China (Grant No.51204034).

\section{References}

[1] Lin N., Huang J.,Dufresne A.,Nanoscale,2012,4, 3274.

[2] Padilha L.A., Nootz G., Olszak P.D.,Nano Lett. 2011,11, 1227.

[3] Eswaraiah V.,Balasubramaniam K.,Ramaprabhu S., Nanoscale, 2012,4,1258.

[4] Meng H.,Xie F.Y.,Chen J.,Nanoscale,2011,3,5041.

[5] Atanasov V., Dandoloff R., Phys. Lett. A ,2009,373,716.

[6] Izumi T., Izumi K., Kuroiwa N., J. Alloys Compd., 2009, 480,123.

[7] Li Z.Y., Liu Y., Gong P.W., Rare Metals,2007,26,476.

[8] Ifuku Shinsuke; Saimoto Hiroyuki, Nanoscale,2012, 4,3308.

[9] Kashani-Motlagh M.M., Mahmoudabad M.K.,J. Sol-Gel Sci. Technol ,2011,59,106.

[10] Wang G.M.,Lu X.H.,Zhai T.,Nanoscale, 2012,4,3123.

[11] Rogojan R., Andronescu E., Iliescu I., Trusca R., Vasile B.S.,Rew. Rom. Mater. ,2011,41, 230.

[12] Xing R.M., Liu S.H.,Nanoscale,2012,4,3135.

[13] Chen J.C. Chen W.C., Tien Y.C., Shih C.J., J. Alloy. Compd.,2010,496,364.

[14] Liu C., Liu P., Lu X.G., Gao C.J., Zhu G.Q., Chen X.M., Powder Technol.,2011,212,299.

[15] Pant P., Naik B.D., Ghosh N.N.,Mater. Technol. ,2009,24, 213.

[16] Lee D.W., Lee J.M., Yu J.H., Rev. Adv. Mater.Sci., 2011, 28,44.

[17] Li Z.Y., Zhai Y.C., Tian Y.W., Rare Metal Mater. Eng., 2005, 34, 966.

[18] Li Z.Y., Zhai Y.C.,Rare metal mate. eng.,2010,39,6. 
[19] Li Z.Y., Gao Y., Jin Duo.,Adv. Mater.Research, 2011, 160-162, 456.

[20] Garcia C., Martin F., Blanco Y., Corros. Sci. ,2010,52,3725.

[21] Selvaraj M. ,Anti-Corrosion Methods and Mater.,1997,44, 13.

[22] Andersson O.K.,Adv. Filtr. Sep. Technol. ,1999,13A-13B, 845.

[23] Xu Y.L., Zhou Z.J., Li M.,Rare metal mater. eng, ,2010,39, 89.

[24] Chen G., Su B., Chen D., Zhang F.Q., Chen Z.H. ,The Chinese J.Nonferrous Metals,2005,15, 584.

[25] Zhao X.M., Xu J., Zhu X.X, Zhang S.M., Zhu P.X.,J. University of Sc. Technol. Beijing ,2009,3,1270.

[26] Zheng F., Zhang Q., Cheng T.Y., Wu W.S., Xue W.F., Metal Mater. Metal. Eng.,2009,37,10. 